\title{
SUBANTARCTIC LIMPET POPULATIONS TODAY AND HUMAN IMPACT ABOUT 1,400 YEARS AGO
}

\author{
POBLACIONES ACTUALES DE LAPAS SUBANTÁRTICAS E IMPACTO \\ ANTRÓPICO CERCA DE 1.400 AÑOS ATRÁS
}

Sven Thatje $\&$ Carlos Ríos $^{2}$

\begin{abstract}
Age, growth and length frequency data of the subantarctic intertidal limpets Nacella (Patinigera) magellanica and Nacella (Patinigera) deaurata (Gmelin, 1791) were investigated at Bahía Laredo in the eastern part of the Straits of Magellan (South America). Data were obtained from (i) recent populations and (ii) from shells of the same species, excavated from an Indian tribe kitchen midden nearby. Conventional ${ }^{14} \mathrm{C}$ age determination showed the shells of both limpet-species from this midden to be about 1,400 years old (S.D. \pm 75 years). Growth rates of recent and ancient populations were found to be in the same range, but higher than determined in previous studies carried out in the Magellan region. The missing of large-sized limpets from the ancient length frequency distributions may indicate considerable exploitation of limpet populations by Patagonian natives about 1,400 years ago.
\end{abstract}

Key words: Magellan region, intertidal, kitchen midden, invertebrates, Gastropoda, limpets, growth

\section{RESUMEN}

Se investigó la edad, crecimiento y frecuencia de tamaños en poblaciones intermareales de las lapas subantárticas Nacella (Patinigera) magellanica y Nacella (Patinigera) deaurata (Gmelin, 1791) localizadas en bahía Laredo, sector oriental del estrecho de Magallanes (Sudamérica). Los datos fueron obtenidos de: i) poblaciones actualmente presentes en el intermareal, y ii) conchas de las mismas especies recolectadas desde un fogón indígena próximo al sitio de muestreo intermareal. Las determinaciones convencionales de edad con ${ }^{14} \mathrm{C}$ mostraron que las conchas de ambas especies de lapas extraídas desde el conchal tienen aproximadamente 1.400 años (D.E. \pm 75 años). Las tasas de crecimiento calculadas tanto para las poblaciones recientes como para las antiguas, fluctúan dentro del mismo rango, aunque son mayores a las determinadas en estudios previos realizados en la región de Magallanes. La ausencia de lapas de gran tamaño en las distribuciones de frecuencias de tallas de las poblaciones del conchal puede indicar que, hace unos 1.400 años atrás, los indígenas realizaban una notable explotación de estos invertebrados.

Palabras clave: Región de Magallanes, intermareal, fogones, invertebrados, Gastropoda, lapas, crecimiento

\footnotetext{
${ }^{1}$ National Oceanography Centre, Southampton, School of Ocean and Earth Science, University of Southampton, European Way, Southampton SO14 3ZH, Southampton, UK; svth@noc.soton.ac.uk

${ }^{2}$ Dirección de Programas Antárticos y Subantárticos, Universidad de Magallanes, Punta Arenas, Chile
} 


\section{INTRODUCTION}

Whereas comprehensive data on age and growth of marine gastropods from different latitudes exist, little information is available from subantarctic environments (e.g. Guzman \& Ríos 1987). Limpets are a main faunistic element of intertidal boulder-cobble fields in the Magellan region (Carcelles \& Williamson 1951, Guzmán 1978, Ríos \& Gerdes 1997), and out of all known subantarctic Nacella species, the South American N. (Patinigera) magellanica and N. (P.) deaurata are among the most intensively studied ones (Dell 1971, Powell 1973, Otaegui 1978).

Before Europeans started to massively settle in the Magellan region during the first half of the 19th century, this remotest part of South America was only inhabited by four indigenous groups (cf Luiz \& Schillat 1998). A permanent human population has been attested to be present in almost all adjacent western parts of the Straits of Magellan and northern Tierra del Fuego since at least 2,500 BP (Borrero 1997). With local variations, all of these native groups complemented terrestrial food resources with the exploitation of the marine and coastal fauna (Borrero 1997). Intertidal limpets are easy to collect and were regularly gathered during low tide, and therefore limpets' meat contributed an important part to their daily nutrition and/or their shells were used as simple tools (Gómez-Otero 1994)1. At present, this circumstance becomes obvious while observing the shoreline of the Straits of Magellan or especially the Beagle Channel, where discarded shells, mostly overgrown by grass, form large and very conspicuous accumulations, which accompany the shores almost everywhere. These middens basically consist of limpet shells of Nacella (Patinigera) magellanica and N. (P.) deaurata in thick layers (Borrero 1997), sometimes mixed with bones, ash and other hunting relicts.

In this study, we compare age, growth, and length frequency data of $N$. (P.) magellanica and $N$. (P.) deaurata obtained from recent populations in the Straits of Magellan (Bahía Laredo) and from shells of populations excavated from an about 1,400 years old deposit layer of a shell midden nearby. We follow up the question of whether i) limpet growth, age, and population structure varies between the populations studied, and whether ii) the exploitation of limpet populations by humans may have affected ancient limpet populations.

\section{MATERIAL AND METHODS}

Data collection

Individuals of Nacella (Patinigera) magellanica and Nacella (Patinigera) deaurata (Gmelin, 1791) were randomly collected from an intertidal boulder-cobble field at Bahía Laredo (52 $56.5^{\circ} \mathrm{S} ; 7^{\circ} 50^{\circ} \mathrm{W}$; cf Ríos \& Gerdes 1997) in the eastern part of the Straits of Magellan. Sampling was performed during low tide in August 1998 on two transects, each of about 18 $\mathrm{m}$ length and $1 \mathrm{~m}$ width, from the shoreline to the lower water level. All specimens of both species were collected from these transects and preserved in $4 \%$ hexamethylenetetramine buffered formalin. In the laboratory the shells were dissected from the meat.

Shells of both species were excavated from the deepest stratum of an Indian kitchen midden situated about $50 \mathrm{~m}$ behind the shoreline of Bahía Laredo nearby the intertidal sampling field. The material was dried in the sun for 2 hours, carefully cleaned with a brush and kept in plastic bottles. In the lab total length and weight of all collected shells were determined.

\section{Growth analysis}

Following earlier investigations on molluscs, we interpreted the conspicuous growth bands on the outer surface of the limpet shells as annual growth marks (Wilbur \& Owen 1964, Picken 1980, Williamson \& Kendall 1981, Guzmán \& Ríos 1987). Each growth band number and corresponding shell length was treated as one age-length data pair. The von Bertalanffy growth function (VBGF) (von Bertalanffy 1938) was fitted to these data using a non-linear least-square method (SIMPLEX algorithm, Press et al. 1986):

$$
\mathrm{L}_{\mathrm{t}}=\mathrm{L} \infty\left(1-e^{-\mathrm{K}(\mathrm{t}-\mathrm{t})}\right)
$$

where $\mathrm{L}_{\infty}$ is the asymptotic length $(\mathrm{mm}), \mathrm{k}$ the growth constant $\left(\mathrm{yr}^{-1}\right)$, $\mathrm{t}$ the age (yr) and to the age at zero length.

\section{Determination of geological age}

We measured stable carbon isotopes of the carbon samples from limpet shells from the kitchen midden with a Finnigan MAT-251 Accelerator Mass Spectrometre (AMS) coupled to an automatic carbonate preparation device. The precision of this method for samples younger than 2,000 years is between

\footnotetext{
${ }^{1}$ Gómez-Otero, J. 1994. Reseña sobre la arqueología en la Provincia de Chubut. Guía de Campo, Séptima Reunión de Campo Cadinqua, Puerto Madryn:93-95.
} 
$0.4-0.5 \%$ based on routine measurements of a laboratory working standard. Stable carbon isotopes were measured by standard techniques (Duplessy 1978, Winn et al. 1991, Stuiver et al. 1993), and are related to the Pee Dee belemnite (PDE) standard through repeated analyses of isotopic reference material (NBS 19) from the National Bureau of Standards (Hut 1987). Additionally, we analysed the age of bone fragments of guanaco (Lama guanicoe), using samples obtained from the same excavation stratum of the kitchen midden, in order to evaluate the quality of our age determination on the marine limpets.

\section{RESULTS}

Stable carbon isotope analysis indicates that the shells of $N$. (P.) magellanica and $N$. (P.) deaurata and the mammal bone fragments (Lama guanicoe) excavated from the Indian dumping place are about 1,360 years old (S.D. \pm 75 years).

Growth (Fig. 1) does not differ distinctly between species or sampling periods (Table 1). Maximum individual age of $N$. (P.) deaurata and N. $(P$.$) magellanica reached 14$ years in recent populations, but only 12 and 11 years, respectively, in the ancient populations from the kitchen midden (Fig. 1). Correspondingly, the largest shell sizes are missing in the ancient size-frequency distribution (Fig. 2). Also the smallest size classes are missing in the samples from the kitchen midden (Fig. 2).

\section{DISCUSSION}

Determination of geological age in calcareous marine organisms is biased by the variability of isotope composition in seawater of shallow marine environments (Emrich et al. 1970, Krantz et al. 1987), which we assessed by using additional terrestrial mammal bones. Problems increase in fossil or even very old deposited shells, which in most cases are affected by secondarily deposited carbonate in shells and which affect conventional or AMS ${ }^{14} \mathrm{C}$ age methods, thus generally leading to overestimations of geological age. Shells excavated from the kitchen midden were preserved in an excellent condition, and even a trained eye is almost unable to distinguish between ancient and recent shells. The kitchen midden is embedded in sandy sediments and overgrown by grass and patchy distributed bushes. This is a rather dry environment with a high drainage effect and hence likely to minimize secondary carbon deposition.

Aging of limpets by counting growth bands on the outer shell may be a questionable method, because (i) there is no direct proof that these bands are formed annually, and because (ii) it might be difficult to distinguish between true "growth" bands and frequently formed "disturbance" marks (see Brêthes et al. 1994, Guzmán \& Ríos 1987). Nevertheless, growth band data were frequently shown to give comparable results to e.g. growth estimations from length frequency data and the method seems to be widely established (e.g. Gayanilo et al. 1989, Brêthes et al. 1994).

The Straits of Magellan are a relatively young marine environment. The region was covered by ice during the Quaternary glaciations, but about 8.000 years ago the surrounding oceanic waters entered into the Straits of Magellan (Clapperton 1994, Clapperton et al. 1995). The quite similar growth rates of recent and ancient limpets may indicate the local climate in the study area to be rather stable, at least over the last 1,400 years.

Europeans settled in the Magellan region during the 19th century and drove all local Indian groups to extinction within a few decades (Luiz \& Schillat 1998). Also, our study area is situated on a protected area of a local gas exploration company (ENAP), which does not allow for any recent direct human impact on the intertidal area of Bahía Laredo. Hence, we can assume the recent intertidal limpet communities to be in a natural stage not affected by human impact over the recent past, for at least 30 years.

Comparing the ancient and recent limpet populations, their size frequency distributions (Fig. 2) and maximum age attained indicate that exploitation by Indians was biased towards larger sized limpets. Small size classes are under-represented in the kitchen midden and had probably not been sampled, and very large and old individuals are missing completely, presumably as an effect of regular exploitation of the populations.

Kelp gulls and oystercatchers are known to feed selectively on large limpet sizes in the Antarctic (Hockey \& Branch 1984, Branch 1981, 1985, Fraser 19892, Nolan 1991). In the Antarctic and sub-Antarctic, kelp gulls were frequently shown to depend on intertidal limpets (Nacella concinna) as a main food resource, because of limited feeding

\footnotetext{
2 Fraser, W.R. 1989. Aspects of the ecology of kelp gull (Larus dominicanus) on Anvers Island, Antarctic

Peninsula. PhD Thesis, University of Minneapolis
} 
alternatives (Ealey 1954, Shabika 1971, Walker 1972, De Villiers 1976, Simpson 1976, Branch 1985, Castilla \& Rozbaczylo 1985, Silva et al. 1999). For this reason a strong predatory competition between Indians and these natural predators may have existed. Since the predatory pressure of Indians disappeared this ecological gap has been closed by natural predators, such as oystercatchers and kelp gulls. However, the comparison of the ancient and extant limpet populations (Fig. 2) clearly reveals that the predatory pressure imposed by Indians was much higher than that of any other natural predators combined.

TABLE I. Growth parameters for Nacella magellanica and Nacella deaurata. $\mathrm{t}^{0}=$ theoretical age at length zero; $\mathrm{K}=$ instantaneous growth rate; $\mathrm{L} \infty=$ asymptotic length $(\mathrm{mm}) ; \mathrm{AM}=$ maximum recorded age (years); $\mathrm{LT}=$ maximum recorded length $(\mathrm{mm})$.

\begin{tabular}{l|c|c|c|c|c|c|}
\multicolumn{1}{c|}{ Species/locality } & $\mathrm{L}$ & $\mathrm{K}$ & $\mathrm{M}$ & $\mathrm{t}_{\odot}$ & $\mathrm{LT}$ & $\mathrm{AM}$ \\
\hline N. magellanica (1998) & 150 & 0.17 & 0.3 & 0.11 & 61 & 14 \\
\hline N. magellanica (kitchen midden) & 145 & 0.18 & 0.29 & 0.11 & 57 & 11 \\
\hline N. deaurata (1998) & 134 & 0.17 & 0.28 & 0.12 & 71 & 14 \\
\hline N. deaurata (kitchen midden) & 145 & 0.17 & 0.28 & 0.11 & 59 & 12 \\
\hline
\end{tabular}

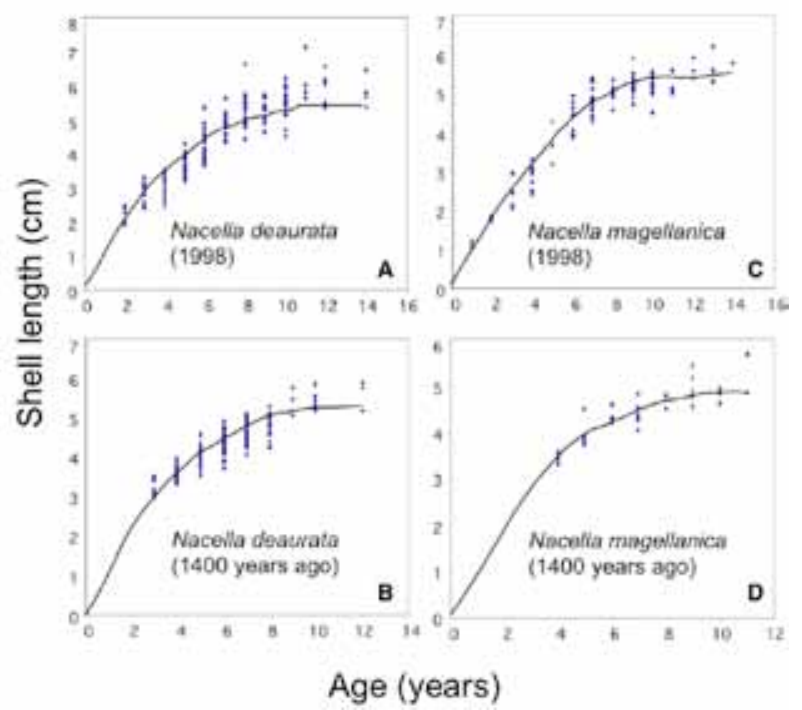

Fig. 1. Von Bertalanffy growth curves for four limpet populations in the Straits of Magellan (Bahía Laredo), Chile. Nacella deaurata (A, B), Nacella magellanica (C, D). 


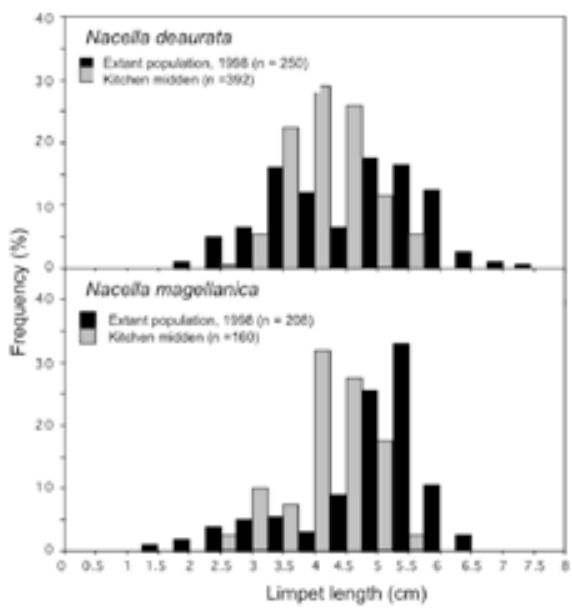

Fig. 2. Size frequency distributions of Nacella deaurata and Nacella magellanica from the Straits of Magellan (Bahía Laredo), Chile.

\section{ACKNOWLEDGEMENTS}

The first author's thanks are due to Dohong Kim for his helpful discussions on the topic. Dr. Helmut Erlenkeuser (Leibniz-laboratory, University of Kiel, Germany) performed the ${ }^{14} \mathrm{C}$ analysis. We would like to thank Dra. Sandra Gordillo and an anonymous reviewer for their constructive commenting on an earlier draft of this work.

\section{LITERATURE CITED}

Borrero, L.A. 1997. The origins of ethnographic subsistence patterns in Fuego-Patagonia. In: Patagonia (eds. McEwan, C., L. Borrero \& A. Prieto), Princeton Univ Press, New Jersey: 60-81.

Branch, G.M. \& L.M. Branch 1981. Experimental analysis of intraspecific competition in an intertidal gastropod, Littorina unfasciata. Australian Journal for Marine and Freshwater Research 32:573-589.

Branch, G.M. 1985. The impact of predation by kelp gulls Larus dominicanus on the SubAntarctic Limpet Nacella delesserti. Polar Biology 4:171-177.

Brêthes, J.C., G. Ferreyra \& S. de la Vega 1994. Distribution, growth and reproduction of the limpet Nacella (Patinigera) concinna (Strebel 1908) in relation to potential food availability, in Esperanza Bay (Antarctic Peninsula). Polar Biology 14:161-170.
Carcelles, A.R. \& S. Williamson 1951. Catálogo de los moluscos marinos de la Provincia Magallánica. Museo Argentino de Ciencias Naturales Bernardino Rivadavia, Ciencias Zoológicas 2:225-383.

Castilla, J.C. \& N. Rozbaczylo 1985. Rocky intertidal assemblages and predation on the gastropod Nacella (Patinigera) concinna at Robert Island, South Shetland, Antarctica. Serie Científica INACH 32:65-73.

Clapperton, C.M. 1994. The quaternary glaciation of Chile: a review. Revista Chilena de Historia Natural 67:369-383.

Clapperton, C.M., D.E. Sugden, D.S. Kaufman \& R.D. McCulloch 1995. The last glaciation in central Magellan Strait, southernmost Chile. Quaternary Research 44:133-148.

De Villiers, A.F. 1976. Littoral ecology of Marion and Prince Edward Islands (Southern Ocean). South African Journal Antarctic Research (Suppl.) 1:1-40.

Dell, R.K. 1971. The marine Mollusca of the Royal Society Expedition to southern Chile, 195859. Records Dominium Museum 7:155-233.

Duplessy, J.C. 1978. Isotope studies. In: Gribbin, J. (ed.). Climatic Change. Cambridge University Press:47-67.

Ealey, E.H.M. 1954. Analyses of stomach contents of some Heard Island birds. Emu 54:204-210.

Emrich, K., Erhalt, D.H. \& J.C. Vogel 1970. Carbon 
isotope fractionating during the precipitation of calcium carbonate. Earth and Planetary Science Letters 8:363-371.

Gayanilo, F.C., M. Soriano \& D. Pauly 1989. A draft guide to the complete ELEFAN. ICLARM Software 2, 70. International Center for Living Aquatic Resources Management, Manila, Philippines, p 70.

Guzmán, L.F. 1978. Patrón de distribución espacial y densidad de Nacella magellanica (Gmelin, 1791) en el intermareal del sector oriental del Estrecho de Magallanes (Mollusca: Gastropoda). Anales Instituto Patagonia, Serie Cs. Nat., (Chile) 9:205-219.

Guzmán, L.F. \& C.F. Ríos 1987. Age and growth of the subantarctic limpet Nacella (Patinigera) magellanica magellanica (Gmelin, 1791) from the Strait of Magellan, Chile. Veliger 30(2):159-166.

Hockey, P.A.R. \& G.M. Branch 1984. Oystercatchers and limpets: impact and implications. A preliminary assessment. Ardea 72:199-206.

Hut, G. 1987. Stable isotope reference sample for geochemical and hydrological investigations. Report $N^{\circ} 42$, International Atomic Energy Agency, Vienna.

Krantz, D.E., F.D. Williams \& D.S. Jones 1987. Ecological and paleoenvironmental information using stable isotope profiles from living and fossil molluscs. Palaeogeography Palaeoclimatology Palaeoecology 58:249-266.

Luiz, M.T. \& M. Schillat 1998. El inicio de la colonización de los territorios australes. In: Tierra del Fuego, Materiales para el estudio de la Historia Regional (eds. Luiz, M.T. \& M. Schillat), Ushuaia, Fuegia, Argentine, p 141-204.

Nolan, C.P. 1991. Size, shape and shell morphology in the Antarctic limpet Nacella concinna at Signy Island, South Orkney Islands. Journal of Molluscan Studies 57:225-238.

Otaegui, A.V. 1974. Las especies del genero Patinigera Dall, 1905 en la Provincia Magallánica (Mollusca, Gastropoda, Prosobranchiata). Physis B. Aires 33:173-184.

Picken, G.B. 1980. The distribution, growth and reproduction of the Antarctic limpet Nacella (Patinigera) concinna (Strebel, 1908). Journal of Experimental Marine Biology and Ecology 4:71-85.
Powell, A.W.B. 1973. The patellid limpets of the world (Patellidae). Indo-Pacific Mollusca 3:75-206. Press, W.H., B.P. Flannery, S.A. Teukolsky \& W.T. Vetterling 1986. Numerical recipes. The art of scientific computing. Cambridge University Press.

Ríos, C. \& D. Gerdes 1997. Ensamble bentónico epifaunístico de un campo intermareal de bloques y cantos en Bahía Laredo, Estrecho de Magallanes. Anales Instituto Patagonia, Serie Cs. Nat., (Chile) 25:47-55.

Shabika, S.V. 1971. The general ecology of the Antarctic limpet Patinigera polaris. Antarctic Journal of the US 6:160-162.

Silva, M.P., M. Favero \& M.M. Martínez 1999. Prey size selectivity by kelp gulls on Antarctic limpets at King George Island, Antarctica. Polar Biology 21:397-400.

Simpson, R.D. 1976. Physical and biotic factors limiting the distribution and abundance of littoral molluscs on Macquarie Island (SubAntarctic). Journal of Experimental Marine Biology and Ecology 21:11-49.

Stuiver, M. \& R.J. Reimer 1993. Extended ${ }^{14} \mathrm{C}$ database and revised calib $3.0{ }^{14} \mathrm{C}$ age calibration program. Radiocarbon 35:215-230.

Von Bertalanffy, L. 1938. A quantitative theory of organic growth (Inquiries on growth laws). II. Human Biology 10:181-213.

Walker, A.J.M. 1972. Introduction to the ecology of the antarctic limpet Patinigera polaris (Hombron \& Jaquinot) at Signy Island, South Orkney Islands. British Antarctic Survey Bulletin 28:49-69.

Winn, K., M. Sarnthein \& H. Erlenkeuser 1991. $\delta^{18} \mathrm{O}$ Stratigraphy and chronology of Kiel sediment cores from the East Atlantic. Report des Geologisch Paläontologischen Instituts der Universität Kiel 45:43-53.

Wilbur, K.M. \& G. Owen 1964. Growth. In: Physiology of Mollusca. Wilbur, K.M., \& C.M. Yonge (eds.). Academic Press Vol. I:211-242.

Williamson, P. \& M.A. Kendall 1981. Population age structure and growth of the trochid Monodonta lineata determined from shell rings. Journal of the Marine Biological Association of the United Kingdom 61:1011-1026. 